\title{
META-ANALYSIS: CORRELATION BETWEEN HYPERTENSION AND SEVERITY OF COVID-19 INFECTION
}

\author{
Lisa Safaah Novia Larsiani
}

Masters Program in Public Health, Universitas Sebelas Maret

\begin{abstract}
Background: Recent studies found that the virus uses angiotensin-converting enzyme (ACE)-2 as the cell entry receptor and that hypertension as well as cardiovascular disorders frequently coexist with COVID-19 have generated considerable discussion on the management of patients with hypertension. This study aimed to investigate the correlation between hypertension and severity of COVID-19 infection.

Subjects and Method: A systematic review and meta-analysis was conducted by PRISMA flow diagram. The articles were collected from PubMed, Science Direct, Google Scholar, and Springer link databases. Keywords used "Hypertension" OR "High Blood Plessure" AND "Severe COVID-19". Eligibility criteria were defined using the PICO model as follows, (1) population: COVID-19 patients, (2) intervention: high blood pressure or hypertension, (3) comparison: normotension, and (4) outcome: severity of COVID-19. The inclusion criteria were full text observatioal study. Articles that met the criteria were analyzed by Revman 5.3 .

Results: 8 studies from America and China were included into this meta-analysis. 2 cross sectional studies found that hypertensive patients had higher risk of severe COVID-19 infection 1.57 times than non-hypertensive patients $(\mathrm{aOR}=1.57 ; 95 \% \mathrm{CI}=$ 1.19 to 2.07; $\mathrm{p}=0.001$ ). A meta-analysis from cohort studies found hypertensive patients had higher risk of severe COVID-19 infection 1.77 times than non-hypertensive patients $(\mathrm{aOR}=1.77$; $\mathrm{CI} 95 \%=1.16$ to $2.71 ; \mathrm{p}=0.009)$.
\end{abstract}

Conclusion: Hipertension increased the risk of severity of COVID-19 infection.

Keywords: COVID-19, hypertension, severity

\section{Correspondence:}

Lisa Safaah Novia Larsiani. Masters Program in Public Health, Universitas Sebelas Maret. Jl. Ir. Sutami 36A, Surakarta 57126, Central Java. Email: nl.lisasafaah18@student.uns.ac.id. 